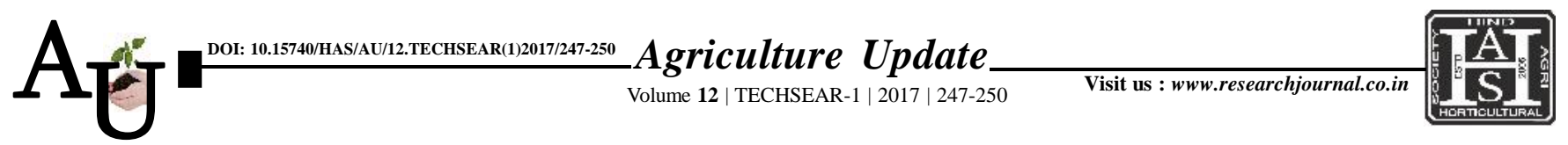

口 e ISSN-0976-6847

\title{
Researcharticle: Growth and yield of soybean [Glycine max (L.) Merrill] as influenced by foliar application of micronutrients and potassium nitrate
}

\author{
MUKESH KUMAR, V.P. SURYAVANSHI AND A.S. DAMBALE
}

Article Chronicle : Received :

11.07.2017;

Accepted :

26.07.2017

KeY Words:

SUMMARY : The experiment was conducted during Kharif season of the year 2015-16 at Experimental Farm, Department of Agronomy, College of Agriculture, Latur, to study the effect of foliar application of micronutrients and potassium nitrate on growth, yield and economics of soybean. The soil was clayey in texture, low in available nitrogen $\left(108 \mathrm{~kg} \mathrm{ha}^{-1}\right)$, low in available phosphorus $\left(8.18 \mathrm{~kg} \mathrm{ha}^{-1}\right)$, very high in available potassium $\left(430 \mathrm{~kg} \mathrm{ha}^{-1}\right)$ and slightly alkaline in reaction $(7.45 \mathrm{pH})$. The experiment laid out in Factorial Randomized Block Design consisting three foliar applications both of micronutrients and potassium nitrate at different growth stagesAmong different application of micronutrients, the application of micronutrients @ $0.5 \%$ at 40 and 60 DAS $\left(\mathrm{M}_{3}\right)$ and among different application of potassium nitrate, application of $\mathrm{KNO}_{3} @ 1 \%$ at $60 \mathrm{DAS}\left(\mathrm{K}_{1}\right)$ produced significantly higher growth, yield contributing characters and yield of soybean.

How to cite this article : Kumar, Mukesh, Suryavanshi, V.P. and Dambale, A.S. (2017). Growth and yield of soybean [Glycine $\max (\mathrm{L}$.) Merrill] as influenced by foliar application of micronutrients and potassium nitrate. Soybean, Multi micro nutrient, Potassium nitrate 